\title{
In situ hybridisation and direct fluorescence antibodies for the detection of Chlamydia trachomatis in synovial tissue from patients with reactive arthritis
}

\author{
J Berlau, U Junker, A Groh, E Straube
}

\begin{abstract}
Background-Chlamydia trachomatis is associated with Reiter's syndrome and reactive arthritis but the form in which the organism survives in synovial cells is unclear.

Aim-To compare in situ hybridisation with direct fluorescence in the detection of inapparent chlamydial infection in synovial tissue.

Methods-Synovial tissue from four patients with reactive arthritis patients was examined using biotin labelled probes for chlamydial DNA and fluorescein isothiocyanate (FITC) labelled monoclonal antibodies against the major outer membrane protein.

Results-In two of the four patients, evidence of chlamydial infections was detected by in situ hybridisation in parallel sections but not with FITC labelled monoclonal antibodies.

Conclusions-Detection of chlamydial DNA by in situ DNA hybridisation may be a better way to identify chlamydial infection in synovial tissue than phenotype targeting with FITC conjugated antibodies, which is used as a standard procedure for screening clinical specimens for chlamydia. (F Clin Pathol 1998;51:803-806)
\end{abstract}

Keywords: Chlamydia trachomatis; reactive arthritis; in situ hybridisation

Chlamydia trachomatis ( $C$ trachomatis) is an obligate intracellular bacterium that plays an important role as a human pathogen responsible for trachoma and sexually transmitted diseases. There is clinical evidence linking $C$ trachomatis with diseases such as Reiter's syndrome and reactive arthritis. ${ }^{12}$ However, although culture of viable $C$ trachomatis from synovial tissue and synovial fluid has been described, ${ }^{3}$ it has not been successfully reproduced. ${ }^{14}$ In contrast, the presence of chlamydial protein antigens, such as major outer membrane protein (MOMP), in joint tissue and synovial fluid has been demonstrated unequivocally. ${ }^{5-7}$ It is therefore not clear whether the disease develops as a result of viable chlamydia or whether it is immune mediated by chlamydial debris deposited in the joint.

Recent studies have shown that chlamydial rRNA and DNA are present in at least some of the joint tissues affected by Reiter's syndrome that proved negative for the organism when using phenotype targeted screening methods such as cell culture and direct fluorescence antibodies. ${ }^{8}$ The former indicates the presence of the whole and viable organism at the infection site; the latter indicates an inapparent infection. To investigate synovial tissue for the presence of apparent and inapparent infections in patients with reactive arthritis, we therefore developed an in situ hybridisation system and compared this with a detection system based on direct fluorescence antibodies (DFA).

\section{Methods}

HYBRIDISATION PROBES

Hybridisation probes were synthesised by polymerase chain reaction (PCR). The following primers were chosen to generate a $151 \mathrm{bp}$ probe of the MOMP gene (p-Ctm) and a $201 \mathrm{bp}$ probe of the $7.5 \mathrm{kB}$ plasmid (p-Ctp) of $C$ trachomatis: CTM-1, 5'-GAT AGC CAG CAC AAA GAG AGC TTA-3' and CTM-2, 5'-TTC ACA TCT GTT TGC AAA ACA CGG TCG AAA ACA AGG-3'; CTP-1, 5'-CTA GGC GTT TGT ACT CCG TCA-3' and CTP-2, 5'-TCC TCA GAA GTT TAT GCA CT- $3{ }^{\prime}{ }^{10}$

Each reaction tube contained $1 \times$ PCR buffer, $2.5 \mathrm{mM} \mathrm{MgCl}, 200 \mu \mathrm{M}$ of dATP, dCTP, and dGTP, $70 \mu \mathrm{M}$ of dTTP, $130 \mu \mathrm{M}$ of dUTP-C ${ }_{16}{ }^{-}$ biotin (all from Boehringer), 1.25 units Taq DNA polymerase (Promega), 10 pmol of each primer, and $1 \mu \mathrm{l}$ template DNA from $C$ trachomatis D IC CAL 8. The PCR protocol was as follows: (1) $94^{\circ} \mathrm{C}$ for five minutes; (2) $94^{\circ} \mathrm{C}$ for one minute; (3) $55^{\circ} \mathrm{C}$ for one minute; (4) $72^{\circ} \mathrm{C}$ for one minute; (5) $72^{\circ} \mathrm{C} 10$ minutes. Steps (2) to (4) were repeated 35 times. PCR products were analysed in $0.8 \%$ agarose gels. Incorporation of biotin was confirmed on nylon filters by means of the Vectastain ABC-AP kit (Vector Laboratories) according to the manufacturer's instructions, after Southern blotting of the agarose gel. The synthesised biotinylated probes were purified using a gel extraction kit (Quiagen) according to the manufacturer and stored at $-20^{\circ} \mathrm{C}$ until use.

PATIENT SAMPLES AND PREPARATION OF SPECIMENS

Synovial tissue was obtained from knee biopsies from five patients within the age range 30 to 45 years and with disease duration of one to four years, attending the surgical clinic of the University of Jena. There were three males with reactive arthritis and the one female with reactive arthritis and rheumatoid arthritis. $\operatorname{IgM}$ and IgG antibodies to chlamydia were present at titres of $1: 32$ or higher. 
The fifth patient had post-traumatic arthritis and was operated on after a severe fall onto the right knee. This patient did not show any signs of chlamydial infection (synovial fluid PCR negative, no $\operatorname{IgM}$ and $\operatorname{IgG}$ antibodies to chlamydia), and sections of synovial tissue from this patient were used as a standard negative control.

Specimens were embedded in paraffin, cut into $5 \mu \mathrm{m}$ sections, and deposited on silane treated slides in the Institute of Pathology, University of Jena. Between 10 and 12 slides, each containing three biopsy sections from each patient, were provided and analysed.

McCoy cell cultures grown on cover slips and infected with various concentrations of $C$ trachomatis were used as standard positive controls and prepared as described previously. ${ }^{11}$

IN SITU HYBRIDISATION

After removal of paraffin as described by Lewis et $a l,{ }^{12}$ fixation in $4 \%$ paraformaldehyde (Sigma) for 15 minutes, and washing in phosphate buffered saline (PBS), the slides were incubated for 20 minutes with $0.2 \mathrm{M}$ $\mathrm{HCl}$. They were washed again followed by incubation for five minute at $37^{\circ} \mathrm{C}$ with a 1 $\mu \mathrm{g} / \mathrm{ml}$ proteinase $\mathrm{K}$ solution (Sigma), then washed in $0.1 \mathrm{M}$ glycine in $0.1 \mathrm{M}$ PBS, and once in $2 \times \mathrm{SSC}(\mathrm{NaCl} /$ sodium citrate). Specimens were prehybridised at $42^{\circ} \mathrm{C}$ for six hours in a solution containing $6 \times \mathrm{SSC}, 45 \%$ formamide deionised, $5 \times$ Denhardt's solution, and $100 \mu \mathrm{g} / \mathrm{ml}$ salmon sperm DNA (all from Sigma). The sections on the slides were denatured for four minutes at $94^{\circ} \mathrm{C}$ on a heating block and hybridised with denatured probe. Probe denaturation was performed by boiling for five minutes, followed by cooling in ice. Hybridisation was performed at $42^{\circ} \mathrm{C}$ for 18 hours overnight in the same prehybridisation buffer containing $250 \mathrm{ng} / \mathrm{ml}$ probe. After hybridisation slides were washed in $2 \times$ SSC at room temperature, followed by a further wash in $2 \times \mathrm{SSC}$ and another in $0.2 \times \mathrm{SSC}$, both at $42^{\circ} \mathrm{C}$. Free binding sites were blocked with $3 \%$ dried milk and the slides were washed in $0.1 \%$ Tween 20 in PBS. Following this, streptavidinalkaline phosphatase (Vector) at $1: 100$ in $0.1 \%$ Tween 20 in PBS was applied to all slides for 20 minutes, followed by one wash in PBS and a second in carbonate buffer $(\mathrm{pH}>8.5)$ containing $0.01 \mathrm{M}$ sodium carbonate and $0.01 \mathrm{M}$ sodium bicarbonate (both from Sigma). The slides were then incubated with 5-bromo-4-

Table 1 Comparison of gene probes $p$-Ctm and p-Ctp with FITC labelled monoclonal antibodies for the detection of Chlamydia trachomatis in synovial tissue of patients with reactive arthritis

\begin{tabular}{llccc}
\hline $\begin{array}{l}\text { Patient (C trachomatis } \\
\text { IgG titre) }\end{array}$ & $\begin{array}{l}\text { Diagnosis and } \\
\text { duration (years) }\end{array}$ & $p$-Ctm & $p$-Ctp & $\begin{array}{l}\text { FITC } \\
\text { mAB }\end{array}$ \\
\hline (1) Male (1:32) & ReA (4) & - & - & - \\
(2) Male (1:32) & ReA (1) & $+(5)$ & $+(6)$ & - \\
(3) Male (1:64) & ReA (1) & - & - & - \\
(4) Female (1:32) & ReA, RA (2) & $+(3)$ & $+(5)$ & - \\
Negative control & Post-traumatic arthritis & - & - & - \\
Positive control & & & & + \\
$\quad$ (10 IFU/coverslip & & + & + & + \\
\hline
\end{tabular}

FITC mAB, fluorescein isothiocyanate conjugated monoclonal antibody; RA, rheumatoid arthritis; ReA, reactive arthritis; +, positive; - , negative; number of positive tissue sections in brackets. chloro-3-indolyl phosphate and nitroblue tetrazolium substrate (Sigma), prepared according to the manufacturer's instructions. Slides were washed in water, counterstained with fast green (Sigma), mounted in glycerol gelatine (Serva), and read by light microscopy. At least 10 slides each containing three tissue sections were investigated for each patient.

\section{DIRECT FLUORESCENCE CYTOLOGY}

Slides and cells on coverslips were prepared as described above. The cells were fixed with absolute methanol for 10 minutes and incubated at $37^{\circ} \mathrm{C}$ for 30 minutes with a fluorescein isothiocyanate conjugated monoclonal antibody (Syva) targeting the MOMP of $C$ trachomatis, washed in PBS, and mounted as recommended by the manufacturer. Slides were read the same way as in situ hybridisation slides.

Initial studies of the newly developed in situ hybridisation system addressed the question of sensitivity. McCoy cells were infected with dilutions of infection forming units of $C$ trachomatis D IC Cal 8 ranging from 0 to $10^{3}$ as described. ${ }^{11}$ After 48 hours, these infected cells were hybridised with both probes and incubated with labelled monoclonal antibodies as described above.

\section{Results}

The initial study comparing the sensitivity of in situ hybridisation and direct fluorescence antibodies in infected McCoy cells showed similar numbers of signals for both methods (infection of $10^{4}$ cells with $10^{1}$ IFU: 8-10 inclusions per coverslip detectable). Positive signals were confined to inclusions and uninfected cells did not show any signals.

MOMP-PCR examination ${ }^{9}$ of synovial fluid of patients 2 and 4 showed positive results, and patients 1 and 3 showed negative results. Examination of synovia of all five patients with FITC labelled monoclonal antibodies against the MOMP showed negative results (data not shown).

The results of the investigation of synovial tissue from four patients are shown in table 1. In two of the samples from patients with reactive arthritis there were unequivocal hybridisation signals in the synovial tissue. These signals were observed in the subsynovial cell layer just below the lining cells (fig 1) or in deeper layers (fig 2) and seem to be located within cells rather than being distributed through extracellular compartments (fig 1). Five or six sections, depending on the probe used, of the 36 sections from patient 2 showed such positive signals just below the lining cells. The five parallel sections were positive with both probes. In patient 4 there were slightly fewer positive signals, all in deeper layers. Three of the parallel sections were positive with both probes (table 1 ). None of the 24 parallel sections of the negative control (patient 5) showed any hybridisation signal with either probe. When tested with FITC conjugated monoclonal antibodies, none of 9-15 parallel sections from each patient gave positive results. 


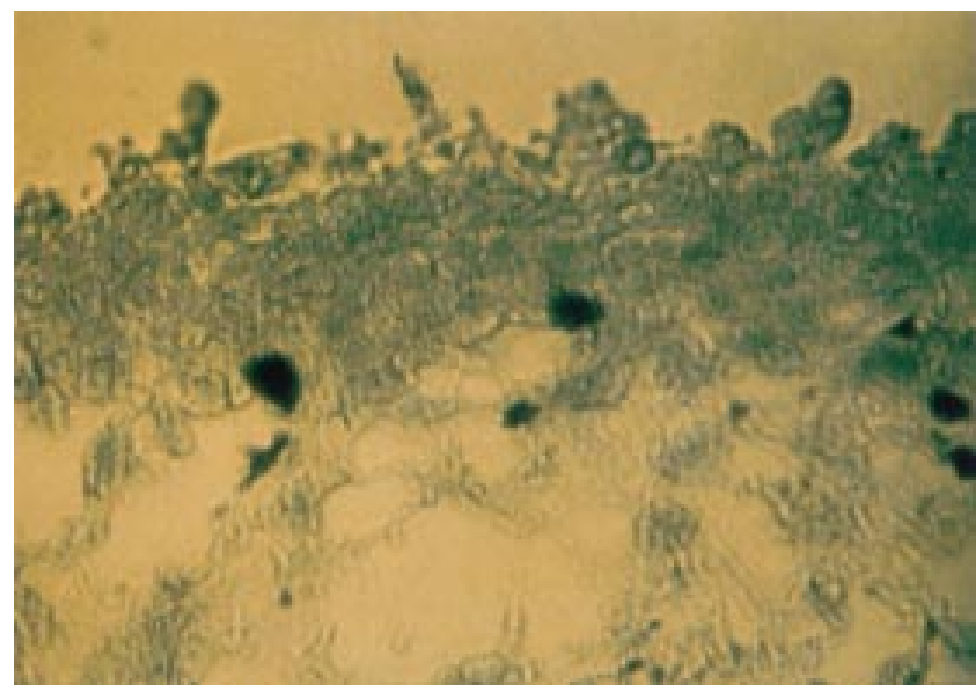

Figure 1 In situ hybridisation with probe p-Ctp to visualise Chlamydia trachomatis in synovial tissue of patient 2 shows that signals are located within the subsynovial cell layer just below the lining cells and appear to be within the cell department rather than in deeper extracellular compartments. Sections of tissue were counterstained with fast green (magnification $\times 360)$.

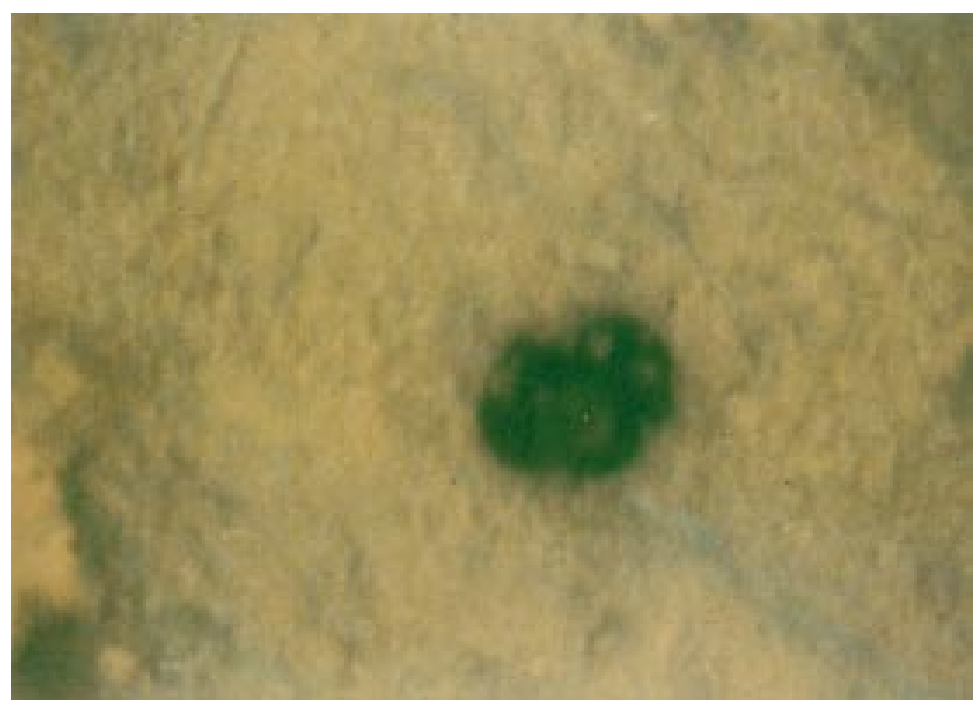

Figure 2 In situ hybridisation with probe p-Ctm in synovial tissue of patient 4 with reactive arthritis. Signals deep in subsynovial layer. Sections of tissue were counterstained with fast green (magnification $\times 895)$.

\section{Discussion}

It has been known for a long time that, along with other bacteria, $C$ trachomatis plays a role in diseases such as reactive arthritis and Reiter's syndrome. ${ }^{13-15}$ Nevertheless, owing to the failure to isolate microorganisms from the affected joint, the term "reactive" was used in 1969 to describe an obviously sterile synovitis following an infection localised elsewhere in the body. ${ }^{15}$ The apparent absence of viable organisms, together with the demonstration of bacterial antigens in synovium and synovial fluid, led to the view that both reactive arthritis and Reiter's syndrome are immune mediated diseases. ${ }^{14}$ Intra-articular chlamydial antigen has been detected ${ }^{1716}$ in inflamed joints, and intracellular persistence of antigens such as major outer membrane protein and lipopolysaccharide in cells has also been shown, the detection of RNA indicating living organisms at the site of infection. ${ }^{9}{ }^{17}$ Some investigators have therefore postulated an inapparent infection which is characterised by persistence of the whole bacterium in a viable state. ${ }^{8}$ In this state, the bacterium is undetectable by phenotypic screening methods but can be seen using nucleic acid directed methods. ${ }^{8}$ Such organisms may play a crucial role in recurrent arthritis $^{18}$ as well as in an obviously sterile synovitis.

To investigate the hypothesis that inapparent chlamydial infections occur in the joints of patients with reactive arthritis, we employed an in situ hybridisation method consisting of two PCR generated probes directed against the endogenous plasmid and the MOMP gene. In two of the four patients, evidence of chlamydial infection was detected by in situ hybridisation in parallel sections. In both the cases, the signals were concentrated in a subsynovial layer but not in the synovial lining itself. The size of the inclusions indicates that the organisms might be in a reticulate body-like state rather than in an elementary body-like state. Despite having equal sensitivity, direct fluorescence antibodies - which are viewed as the gold standard for screening for chlamydia-failed to detect these organisms. This might indicate the suppression, or even the absence, of synthesis of the major outer membrane protein, which is normally found in both reticulate and elementary bodies. ${ }^{80}$ Thus the results of our study may partly explain the failure to culture chlamydia from synovial tissue of patients with reactive arthritis, and they confirm the view of an inapparent chlamydial infection in at least some patients with reactive arthritis, as postulated by other investigators. $^{81920}$ This might even suggest a previously undescribed stage of the chlamydial life cycle. ${ }^{8}$ Such inapparent organisms could be critical in the pathogenic process leading to arthritis. ${ }^{18}$

It will be the task of further investigations to screen larger numbers of patients and characterise these unusual organisms to determine the specific cell types harbouring them.

We are very grateful to Dr H Kosmehl and Ms C Rudolph, Jena, for providing the tissue sections and to Dr T L Pitt and Dr H M Aucken, London, for reading the manuscript.

1 Keat ACS, Thomas B, Dixey J, et al. Chlamydia trachomatis and reactive arthritis: the missing link. Lancet 1987;i:72-4.

2 Kingsley G, Sieper J. Current perspectives in reactive arthritis. Immunol Today 1993;14:387-91.

3 Schachter J, Barnes MG, Jones JP, et al. Isolation of Bedsoniae from the joint of patients with Reiter's syndrome. Proc Soc Exp Biol Med 1966;122:283-5.

4 Gordon FB, Quan AL, Steinman TE, et al. Chlamydial isolates from Reiter's syndrome. Br f Venereal Dis 1973;49: lates from

5 Keat ACS, Thomas BJ, Dixey JJ, et al. Intrasynovial chlamydial antigen in human arthritis. In: Proceedings of the European Society for Chlamydia Research. Stockholm: Almquist and Wiksell International, 1988:156-8.

6 Keat ACS. Genes, bacteria and the key to arthritis. Trans Med Soc Lond 1989;106:83-92.

7 Ishikawa $\mathrm{H}$, Ohno $\mathrm{O}$, Yamasaki $\mathrm{K}$, et al. Arthritis presumably caused by chlamydia in Reiter's syndrome. $\mathcal{F}$ Bone foint Surg [Am] 1986;68:777-9.

8 Beutler AM, Whittum-Hudson JA, Nanagara R, et al. Intracellular location of inapparently infecting chlamydia in synovial tissue from patients with Reiter's syndrome. Immunol Res 1994;13:163-71.

9 Holland SM, Hudson AP, Bobo L, et al. Demonstration of chlamydial RNA during a culture-negative state. Infect Immun 1992;60:2040-7.

10 Vogels WHM, van Voorst Vaader PC, Schröder FP. Chlamydia trachomatis infection in a high-risk population: compari- 
son of polymerase chain reaction and cell culture for diagnosis and follow-up. F Clin Microbiol 1993;31:1103-7.

11 Berlau J, Groh A, Straube E. Improved isolation of Chlamydia pneumoniae from synovial cell cultures by using polyethylene glycol. Med Microbiol Lett 1996;5:167-72.

12 Lewis FA, Griffiths S, Dunicliff R, et al. Sensitive in situ hybridisation technique using biotin-streptavidin-polyalkaline phosphatase complex. F Clin Pathol 1987;40:163-6.

13 Mäki-Ikola O, Granfors K. The bacteriology of reactive arthritis. Rev Med Microbiol 1993;4:144-50.

14 Kingsley G, Sieper J. Second International Workshop on Reactive Arthritis. Meeting report. Clin Exp Rheumatol 1993;11:229-37.

15 Hughes RA, Keat AC. Reiter's syndrome and reactive arthritis: a current view. Semin Arthritis Rheum 1994;24: 190-210

16 Rahman MU, Cheema MA, Schumacher HR, et al. Molecular evidence for the presence of chlamydia in the synovium of patients with Reiter's syndrome. Arthritis Rheum 1992;35:521-9.

17 Schmitz E, Nettelnbreker E, Zeidler H, et al. Intracellular persistence of chlamydial major outer membrane protein, lipopolysaccharide and ribosomal RNA after nonproductive infection of human monocytes with Chlamydia trachomatis serovar K. $\mathcal{F}$ Med Microbiol 1993;38:278-85.

18 Rahman MU, Schumacher HR, Hudson AP. Recurrent arthritis in Reiter's syndrome: a function of inapparent chlamydial infection of the synovium? Semin Arthritis Rheum 1992;21:259-66.

19 Cheema MA, Schumacher HR, Hudson AP. RNA-directed molecular hybridisation screening: evidence for inapparent chlamydial infection. Am F Med Sci 1991;302:261-8.

20 Nanagara R, Li F, Beutler A, et al. Alteration of Chlamydia trachomatis behavior in synovial membranes. Arthritis Rheum 1995;38:1410-17.

\section{Fournal of Clinical Pathology - http://www.jclinpath.com}

Visitors to the world wide web can now access the fournal of Clinical Pathology either through the BMJ Publishing Group's home page (http://www.bmjpg.com) or directly by using its individual URL (http://www.jclinpath.com). There they will find the following:

- Current contents list for the journal

- Contents lists of previous issues

- Members of the editorial board

- Information for subscribers

- Instructions for authors

- Details of reprint services.

A hotlink gives access to:

- BMJ Publishing Group home page

- British Medical Association web site

- Online books catalogue

- BMJ Publishing Group books.

The web site is at a preliminary stage and there are plans to develop it into a more sophisticated site. Suggestions from visitors about features they would like to see are welcomed. They can be left via the opening page of the BMJ Publishing Group site or, alternatively, via the journal page, through "about this site". 